\title{
Discussion on Autonomy Principle in Law of the Application of Law for Foreign Civil Relations
}

\author{
Yitong Wang ${ }^{1}$ \\ ${ }^{1}$ School of Humanities and Social, North China Electric Power University, China
}

\begin{abstract}
Keywords: Autonomy of will, Application of law, Applicable law, Restrict, Development
\end{abstract}
\begin{abstract}
The principle of party autonomy was first proposed by Dumoulin, a French scholar in $16^{\text {th }}$ century, and gradually evolved into the basic principles in the field of foreign contracts. Later, with the advancing of legislation technology in nations, the principle of party autonomy is penetrating into other areas. Our nation referenced the most advanced legislative experiences, giving fully play the functions of principle of autonomy, resulting a more flexible application method and more comprehensive applied sphere, which made a great contribution in the field of international private law. In this paper, based on the value and status of the principles of autonomy in Law of the Application of Law for Foreign Civil Relations (thereinafter called Law of Application for short), and elaborate the restriction of other fields like real right, creditor's right, intellectual property right, marriage and family on its development.
\end{abstract}

\section{Introduction}

Originally, the principle of party autonomy is regarded as "golden rule" and widely used in the field of foreign contracts. China's Law of Application not only followed the traditional principle of party autonomy, but also made new extensions and limitations, which penetrated into other fields and endowed an important legal status.

\section{Definition and origin of the principle of party autonomy}

The principle of party autonomy means on the basis of agreement, both parties negotiate and select an applicable law governing their rights and obligations relation in foreign civil and commercial relations. When the contract dispute is happened, the court accepts the case should base on the applicable law chosen by the parties. The core of the principle of party autonomy in foreign civil relations is the independent dispose rights of parties.

The principle is originated in the Comments on Paris unwritten law, in which Dumoulin advocated "the law parties negotiated themselves have priority to be applied in contract, in the situation they haven't identified applicable law clearly, the court should choose the one parties prefer based on the specific case". Therefore, Domoulin is regarded as the founder in the field of international private law, called "Father of Private International Law".

\section{The status of principle of autonomy in Law of Application}

In China's Law of Application, the principle of party autonomy is third one in general rules, which means this basic principle can be applied in all the choice of applicable law concerns foreign civil relations. The proportion of related provisions is far more than international private legislation of other advanced countries in the world-among 52 provisions, fifteen of them provided this 
principle, showing its “unusual” status.

Prof. $\mathrm{Xu}$ Junke holds that the "unusual" status of party autonomy principle in our country is mainly represented in following three aspects: first, the structural arrangements and overall number of provisions. That is to say the third article in general provision and fourteen articles in sub-provision all provided both parties can choose applicable law independently. Second, the applied field is expanded. It means the principle of party autonomy in our country's Law of Application is not only applied in traditional contract field, but also respond to the needs of social development, learning from national advanced legislative experiences, and expanding to other fields like tort, real rights, intellectual property rights and marriage. Third, its application scope is limited, which means the limitation from weak protection principle and directly applicable mandatory provisions in the process of autonomy principle ruled in our Law of application.

I agree with prof. Xu's opinion that the importance of this principle is reflected in many aspects, which can be realized from both its positive aspect include the choice scope of the applicable law and the proportion of provisions and its negative aspects of the provisions limiting this principle. Because the rule of restriction is good for the determine of the scope of party autonomy principle, and drawing a red line when this principle gradually penetrated into other fields, which better reflected the emphasis on it in china's law of application.

\section{The intrinsic value of the principle of party autonomy}

The principle of autonomy has freedom, efficiency, fairness and justice and other intrinsic values. Freedom value refers to citizens have the rights to conduct their own volitions and not being limited without violating the law. Efficiency value is means that parties can foresee the results when they independently select the applicable law, improving the predictability of the results, conducive the settlement of the dispute and maximize the interests of the parties. While from the perspective of court lawsuit, given the law autonomy to civil subjects has increased the costs of justice in some extent, for the usage of a foreign law is not applied directly once the parties selected, but need a process of legal identify. There is an old adage called "judge knowing", so the jurisdiction of the court has the duty to identify the law chosen by parties. Justice value, it refers the law of application not only ruled the situation of parties negotiation, but also provides the situation that only the weak side to choose the applicable law, such as in labor relations, workers and consumers in contract can choose the law independently, which reflect the essence of the pursuit of justice value.

\section{The comparison of principle of party autonomy between international private law and civil law}

Personal autonomy is an important feature of private law. The basic meaning of the principle of party autonomy in international law and private law is similar, both refers to the parties have the rights of free dispose in the condition of not violating the law.

To start with, the two is closely connected. The autonomy principle in civil law gradually evolved into international private law of autonomy principle and without former, there is no latter one. Then, foreign civil relations exists differences in the applicable scope, whether can be applied directly or not, the degrees of freedom. First, the scope of autonomy principle is differ. The application of autonomy principle in civil law is applied in all areas that private law allowed, while in international private law is only applicable in the choice of law. Second, they are differ in whether can be applied directly. The applicable law selected by autonomy principle in international private law can't be applied directly, which can serve as a basis by legal identification, distinguish 
and other process. Third, the free degree is different between the two. As in the provision of civil law, the civil subject has the rights to decide how to dispose themselves without violating public order, while its application need to follow the manner, time and scope prescribed by the law. In addition, there are scholars thought they are differ in history development and philosophy. The autonomy principle in civil law is first confirmed in 1804 French civil code, while in international law it was first established in1865 Italian civil code. The philosophy is different. This principle in international law is conduct under the sovereign equality between nations while in civil law, it is influenced by modern social contract theory, supremacy of human rights proposed by Enlightenment thinkers, emphasizing the equal status of social members.

\section{The development of principle of autonomy in our country}

Before the implement of Law of Application, principle of autonomy in our country is only applied in foreign-related contracts. Our law of application not only learned the achievements and experiences from international advanced conflict legislation areas, reflecting the advance aspect in law selection.

Tort field. Tort behavior applied "lex loci actus" is the formulation of dependency recognized worldwide. China's Law of Application stipulates, "After the infringement occurred, if the parties negotiated to choose the applicable law, in accordance with their agreements". Tort behavior applied the autonomy principle mainly because simply taking the "lex loci actus" can't completely fit the flexible and various foreign torts relations, and may result in unfair judgment. Principle of autonomy can fully play the function of parties, strengthen the stability of legal relations and predictability, and flexibly adapt to several of tort relations, improving the conflict efficiency.

Real right field. Ancient "lex loci rei sitae” proposed by Bartulos always been the basic rules followed by real rights relations, which begun to apply the autonomy principles more often with the mature of the legislative technique. There are three reasons: first, some objects like "transporting" is specialized and can't apply the traditional formulation of dependency for can't pinpoint out their location. Second, real rights and creditor's right is closely connected, and can flexibly applied autonomy principle in relevant issues. Third, it is a result of the trend of world. Many countries in European law system have provide this principle can be applied for movable rights.

In China's Law of Application, there are three provisions relating to the principle of autonomy, respectively related to transport material, the trust property and movable property. Because it is difficult to determine the location of the transporting objects, so allow the parties to select the applicable law on their own is more fair and equitable. The trust property is closely connected with claims, the introduction of autonomy principle can ensure the stability and integrity of the trust relationships. The parties can negotiate and choose the law applicable to movable property, if haven't selected, they will applied the applicable law of location the movable property in where the legal facts occurs. The combination of autonomy principle and "lex loci rei sitae" making our conflict rules become more flexible.

Intellectual real right. According to the rule, the parties can choose to apply the applicable law and apply the law of applicable court once the infringement of intellectual property happened in the process of transfer intellectual property and licensing. Liking other nations with a relative complete international private law, our country adopted the "division method", but few of them have fully used autonomy principle in intellectual property and giving the parties more choice as our nation does.

The field of marriage. In the aspect of marital property and divorce can apply the autonomy principle in our country. Law of Application provides that, "in the marital property relations, the 
parties can agree to choose apply the law of one party habitual residence, law of nationality or the law of location most property in.” This provisions controlled the degree of parties' choice freedom in certain scopes. Because marriage is more represent the identity of the person rather than the property, it needs law to ensure social order, and too many autonomy rights will impact on ethical and social order. Only limited selection is contribute to the settlement of disputes, ensure the predictability of cases.

What's more, one bright innovation spot in China's Law of Application is separated the divorce proceedings and divorce law, giving parties the rights to choose applicable law of divorce proceedings. This is benefit to protect the integrity of court's judicial sovereignty, and ensured parties' autonomy dispose right. Meanwhile, our country also defines the select range of divorce law, and selecting within a limited range is respect the party's real purpose in the marriage relations and given attention to its actual connection with legal relationship.

\section{The restriction of autonomy principle in our country}

With the expand of autonomy principles, it should be limited in some aspects, therefore, the law of application in our country provided restrictions in the selection method, selection time and selection content of this principle.

Restriction of selection method. Chinese law provides two kinds of law selection method, they are explicit and implicit. Article 3 in Law of Application provided that, in accordance with the law, parties can explicit select the law applicable in foreign-related relations, and the Article 8(2) provide in judicial interpretation, when both parties are invoking the same countries' law without rising objection, the court finds that parties have made a choice in the applicable law of foreign-related civil relations.

Different scholars are agree the explicit selection method, but exists differences in the aspect of weather our country is allow the choice of implicit method. Some scholars believe that China has acknowledged the implicit way of law selection, while others believe that China recognized only a limited implicit way or haven't recognized it completely. In this aspect, the author believes that according to the understanding of the law, our country is allowed.

Restriction of selection time. The selection time of the law of both parties, it means weather allowed both parties of foreign civil activities to change their law choice or change after the affair. Autonomy principles must limited within a reasonable period of time, which is benefit to promoting judicial efficiency, fast and timely solve disputes. Article 8(2) in judicial interpretation of China's Law of Application provided, "the parties agree to choose or change applicable law before the end of court debate in first instance, the people's court shall permit.”

Restriction of selection content. Our country has clear requirements on the selection law, in order to avoid remission, only recognizing substantive law, excluding applicable law of other countries, and there do not asked an actual connection between chosen law and legal facts. The author believes this provision is reasonable, for fully ensured the autonomy of parties, respect their choice, and restrict the type of selection law and guarantee the integrity of our judicial sovereignty at the same time.

Restriction of the principle to protect the interest of the weak. Generally, the principle of party autonomy requires both parties select the applicable law by equally negotiation. While, in consumer relations and labor relations, consumers and workers obviously in the weak position, the agreement of giving both parties equal choice of law only achieved formal equality, and put them in an adverse condition in fact. Thus, the principle of protection of vulnerable can offset this deficiency, realizing truly fairness and justice. 
In addition, according to the Article 4 in Law of Application, "if our country provided mandatory provisions in foreign civil relations, it can applied directly" we can know that in the situation of exists mandatory provisions, the principle of autonomy can't applied.

\section{Conclusion}

In the general rules of China's Law of Application, it set forth the principle of autonomy, given the legal status of its basic principle. It made a clear provision in different areas like real rights, creditor's right, intellectual property right, marriage and family, but also restricts the principle in the content selection, time selection, manner selection, other principles and mandatory provisions. This is conducive to give full play the function of autonomy principle in foreign-related civil relations, and have an important significance in promoting legal construction of rights-based, ensure the lawful interests of parties and saving judicial resources and the fully realization of freedom value and justice value.

\section{References}

[1] Xie, F. Wang, W. Analysis on the principle of autonomy in Law of Law Application of Foreign Civil Relations. Legal System and Society, 2013, (10). (In Chinese)

[2] Ye, Z. Principle of autonomy in Law of Law Application of Foreign Civil Relations. Western Law Review, 2015, (2). (In Chinese)

[3] Xu, J. Discussion on the status of autonomy principle in Law of Law Application of Foreign Civil Relations. Law Review, 2012, (4). (In Chinese)

[4] Zhang, R. Thinking of the principle of autonomy in Law of Law Application of Foreign Civil Relations. Journal of Anyang Normal University, 2011, (3). (In Chinese)

[5] Li, J. Discussion on principle of autonomy on the applicable law. Business Forum, 2013, (6). (In Chinese)

[6] Zhu, L. Discussion on the expansion and limitation of principle of autonomy in Chinese international private law. Guide to Business, 2013, (16). (In Chinese)

[7] Wang, L. Study on the two-dimensional nature of the principle of autonomy in Law of Law Application of Foreign Civil Relations. Hubei Social Science, 2012, (8). (In Chinese)

[8] Lin, H. Study on the principle of autonomy in Law of Law Application of Foreign Civil Relations. Office Operation, 2012, (6). (In Chinese)

[9] Tang, Q. Discussion on the application of the principle of autonomy in Law of Law Application of Foreign Civil Relations. Journal of Chengdu Administration Institute, 2012, (3). (In Chinese)

[10] Yang, X. Discussion on the principle of autonomy in Law of Law Application of Foreign Civil Relations. Journal of Xingtai University, 2014, (2). (In Chinese) 